\title{
The Implementation of Project Based Learning (Pjbl) Based on STEM: A Reflection of Concept and Reality Within Learning Process in Business Department of Vocational High School
}

\author{
Agung Winarno, Afidzatul Maulana \\ Faculty of Economics, Universitas Negeri Malang \\ Email: agung.winarno.fe@um.ac.id
}

\begin{abstract}
The 21st century education expects students to have the skills to solve problems, develop knowledge, be able to develop high degree of thinking and critical thinking. This expectation requires schools to be able to take an innovative learning approach. This study aims at determining the implementation of the STEM-based Project Based Learning (PjBL) model in General Administration subjects as well as how it impacts student learning outcomes. This research is a survey based on the implementation of Classroom Action Research (CAR) by the practicum teacher. This Classroom Action Research requirements that were included in the observation were at least two cycles with two meetings per cycle. The results showed that the implementation of the STEM-based Project Based Learning (PjBL) model of teachers experienced more problems related to the interpretation of each component of the planning process for the preparation of learning tools and specifically difficulties when the process of real-life context learning activities in class. However, this learning model has provided benefits in strengthening students' learning outcomes.
\end{abstract}

Keywords: Learning Outcomes, STEM approach, Project Based Learning

\section{INTRODUCTION}

One of the most suitable approaches to break the chain of backwardness in a country is through education. By providing a good quality of education, a country can prepare quality successors in the future as well as influence the progress of civilization. The achievement of educating the community's life cannot be separated from the role of a teacher. In specific, teacher is a profession who is tasked with teaching, educating, and guiding, training and building character of learners. Winarno (2015) also directs students to become intelligent people in cognitive, affective, and psychomotor aspects. Teachers in carrying out learning tasks require planning, selecting, and implementing several strategies to assist them in carrying out the teaching and learning process (Utami \& Hasanah, 2020). This planning is able to prepare students who can think critically and be able to solve problems in the surrounding environment.

Vocational High School (SMK) is one of the secondary education units that prioritizes the development of the ability of students to be able to work in one particular field of profession. However, they are not only capable of working in certain fields, vocational students are also required to be able to use their academic knowledge in solving problems in everyday life and in the circumstance of 
professional work. This ability will not be realized without the role of a teacher. Therefore, teachers are expected to be able to implement learning planning that can support the creation of students' abilities (Reis-Jorge, 2005). In the learning planning process the teacher must be able to find out the situations and conditions that are being experienced by their students. So that a teacher can understand how to handle and overcome difficulties that occur in the learning process. Selection of models, methods and strategies is very important, with the right selection it will be able to help students improve their ability to analyze, think critically, and socialize (Darling-Hammond et al., 2019; McCarthy \& Carter, 2006).

The learning method is used as an approach to achieve learning objectives, the operationalization of learning strategies in dealing with individual differences in students, improving learning outcomes, and increasing the acquisition of learning by students and having a direct impact on achieving goals. There are a number of learning models that can improve the learning abilities and learning outcomes of students. One of them is the Project Based Learning (PjBL) learning model. PjBL is a learning model that aims to focus students on the complex problems needed to carry out investigations. $\mathrm{PjBL}$ aims to guide students in a collaborative project that integrates various curriculum subjects, provides opportunities for students to explore content using various ways that are meaningful to themselves and conduct collaborative experiments (Mulyasa, 2013).

The learning model will greatly assist teachers in achieving goals in the teaching and learning process if it is supported by an appropriate learning approach. The process standards for primary and secondary education as regulated in Ministry of Education and Culture Regulation No.65 of 2013 state that the learning process is very important by using the principles of a scientific approach. One of the newest forms of scientific approach that can assist teachers in creating experts is by applied STEM approach. The STEM approach is an approach that is formed based on a combination of several disciplines, specifically Science, Technology, Engineering, and Mathematics (Nessa et al., 2017).

The goals of STEM are identical as the goals of education in the 21st century, particularly, students are able to analyze assumptions, solve problems, develop knowledge, and make decisions they have therefore, the skills can be applied in everyday life (Bybee R., 2013). STEM-based learning can develop if it is associated with the environment, thus, it can create learning that presents the real world experienced by students in everyday life (Quang et al., 2015). This means that through the STEM approach, students are not just memorizing concepts, but more on how students can understand scientific concepts and their relation to everyday life. Therefore, learning in the classroom will be more meaningful for students.

The application of STEM learning can increase the achievement of student learning outcomes inside and outside of school (Kang, 2019; Nurazizah et al., 2018). Project Based Learning by using the STEM approach is very suitable for solving problems that occur in vocational high school, whose competence in current situations requires critical thinking skills and the courage to make correct decisions. This learning will make students active and pay more attention to what is conveyed by the teacher and can integrate solution solutions into the tasks that students are doing. The PjBL learning model with the STEM approach can improve student learning outcomes because in the learning process students are required to be active 
in solving problems and making projects monitored by the teacher. The STEM approach will also stimulate students to be able to solve the problems they face in the classroom and in the real world by integrating the four disciplines in it. The existence of previous research that has been done will prove that this will be able to improve student learning outcomes by using the $\mathrm{PjBL}$ learning model through the STEM approach.

Similarly, Alifa et al. (2018) states that the combination of project-based STEM methods is an effective combination because it involves the active role of students and increases the creativity of students to learn. Furi et al. (2018) in their research stated that learning using PjBL-STEM can improve learning outcomes in the cognitive aspects and psychomotor aspects of students. This study seeks to examine how the process of implementing the Project Based Learning (PjBL) learning model with the Science, Technology, Engineering, and Mathematics (STEM) approach as well as observing its application to enhance students' learning outcomes.

\section{METHODS}

The method used in this research was a survey, in particular, it was a review of the results of the implementation of Classroom Action Research (CAR) carried out by students in carrying out their final assignments as well as exploring various problems during implementation both during planning, implementation and reflection. Data collection was carried out by identifying at the report documents and interviews with students who were practicing CAR implementation at the Vocational School of Business Automation and Office Management major (OTKP) in Malang Regency as well as presenting document analysis on the results of implementing the Project Based Learning (PjBL) model with the Science Technology Engineering approach. and Mathematics (STEM). The data analysis used both descriptive narrative and the learning outcomes of students.

\section{RESULTS \& DISCUSSION}

This study aimed at examining how the process of implementing the Project Based Learning (PjBL) learning model with the Science, Technology, Engineering, and Mathematics (STEM) approach as well as observing its application to the learning outcomes of students. The following are the results of research that has been done.

\section{The Process of Planning and Implementation, and The Obstacles}

The results showed that the practicum teacher experienced a number of difficulties in the planning process, particularly in integrating STEM elements into learning steps on certain basic competencies. The results of the interview also obtained data that not many schools used this approach on the reason that there were insufficient infrastructure to support the application of technological elements within the implementation of learning. This finding is in line with Ejiwale (2013), which states that the biggest concern of implementing the STEM approach is the inadequacy of teachers and infrastructure support. The lack of readiness of the teacher in this 
regard is related to the creativity of integrating the principles of approaches in applicable learning planning implemented in the classroom.

From the technical aspects, the combination of the PjBL learning model with the STEM approach, based on the findings, did not encounter a number of problems. During the implementation of PjBL, if the basic competencies to be achieved are appropriate, then the teacher faces no difficulty in implementing PjBL and students can automatically apply STEM principles when carrying out tasks from the teacher. The implementation of the STEM-based PjBL learning model can overcome the obstacles that occur in the learning process that takes place in class. By implementing the STEM-based PjBL learning model, the classroom atmosphere becomes more conducive. Because this learning model can involve students to be active in the learning process which aims to improve their learning outcomes and can be useful and applied in everyday life (Afriana et al., 2016).

The application of the STEM-based PjBL learning model was implemented in two cycles according to the steps composed in the Lesson Plan that has been prepared previously. Cycle I and cycle II were carried out face to face, each meeting was spent for two hours of session. Learning was started by explaining slightly a lesson content in accordance with the theory by using their own language to make it easier for students to understand. During the presentation of the lesson content by the teacher, students listened and occasionally asked questions about what they were still confused about. At this stage, students' knowledge (science) regarding the application of work/office layout can be improved. Therefore, students are able to design work/office layout designs properly. After delivering the lesson contents, students conducted group discussions. The groups consisted of five up to six students. Each group was given a different topic by the teacher.

After group formation was complete, the teacher explained the flow of discussion to be carried out. The teacher showed a video related to the arrangement of the office layout according to the lesson content being delivered. Then, the teacher gave group assignments. The teacher altogether with students determined the deadline for completing the task. The teacher then monitored students' activity by moving around in each group to see if students face any obstacles. The implementation of the application of the STEM-based PjBL learning model in General Administration subjects with the basic competencies of implementing work/office layout in class X Automation and Office Management major, went well. This learning model is appropriate because it allows students to be more active and contented in participating in class learning (Maulana, 2020; Sukmawijaya et al., 2019). Students are able to improve their thinking skills, follow directions, procedures and steps contained in learning when carrying out discussions or working on projects properly.

The mastery of concepts and the ability of students to think can also be improved with the application of learning using the STEM-based PjBL model. Research conducted by Jauhariyyah et al. (2017) report that the application of the STEM-based PjBL learning model can train the abilities and talents of students in dealing with 21st century problems. This learning can increase scientific literacy, motivation, understanding of lesson content, the ability to think creatively, the effectiveness of meaningful learning, and support future careers. 


\section{The Effect of PjBL on Students' Learning Outcomes}

The application of the PjBL learning model based on the STEM approach carried out by the practicum teacher can be carried out properly according to the stages set out in the PjBL model. Based on the data obtained during the research, it was found that there was an increase in the percentage of the implementation of the STEM-based PjBL learning model from cycle I to cycle II. The obtained result of cycle I was 91.2 percent and the result of cycle II was 96.5 percentage. Figure 1 shows that the percentage increase from cycle I to cycle II was 5.8 percent. This shows that the application of the STEM-based PjBL learning model can be carried out well.

\section{The Results of Cognitive Aspect in the First Cycle}

Student learning outcomes data in cycle I was measured by using posttest questions given to students after the application of the STEM-based PjBL learning model at the end of Cycle I. Based on the results of the posttest, the test scores were obtained and compared with the daily test scores carried out by the General Administration subject teachers which can be seen in Table 1 .

Table 1. The Comparison Between Pre-test and Post-test Scores in the First Cycle

\begin{tabular}{lcc}
\hline \multicolumn{1}{c}{ Remarks } & Pretreatment Scores & Cycle I Posttest Scores \\
\hline Classroom Average Score & 71.1 & 77 \\
$\Sigma$ number of students $\geq$ & 15 & 28 \\
Percentage of improvement & $8.3 \%$ & \\
\hline
\end{tabular}

Based on Table 1, it can be seen that the average data on the results of observations of the implementation of teacher learning at the first meeting was 89.6 percent and at the second meeting was 92.8 percent therefore, the average result of the implementation of the STEM-based PjBL learning model in the first cycle by the teacher was approximately 91.2 percent with the criteria which shows a remarkable change.

\section{The Results of Cognitive Aspect in the Second Cycle}

Student learning outcomes data in the second cycle were measured using posttest questions given to students after the application of the STEM-based PjBL learning model at the end of cycle II. Based on the results of the posttest, the test scores were obtained and compared with the daily test scores carried out by the General Administration subject teachers which can be seen in Table 2.

Table 2. The Comparison Between Post-test Score of First and Second Cycle

\begin{tabular}{lcl}
\multicolumn{1}{c}{ Remarks } & Cycle I Posttest Scores & \multicolumn{1}{c}{ Cycle II Posttest Scores } \\
\hline Classroom Average Score & 77 & 83.5 \\
$\Sigma$ number of students $\geq$ & 28 & 32 \\
Percentage of improvement & $8.4 \%$ & \\
\hline
\end{tabular}

Table 2 illustrates the average score in the posttest in the first cycle was about 77 , while the score in the post-test the second cycle was approximately 83 . Students who exceeded the Minimum Mastery Standard in the first cycle were 28 students. While in cycle II who can exceeded the Minimum Mastery Standard were 32 
students. The percentage of increase after the implementation of the STEM-based PjBL learning model was 8.4 percent.

\section{The Results of Psychomotor Aspect in the First Cycle}

Assessment of the psychomotor domain was obtained from the results of the assessment of practical activities. The results of the psychomotor aspects of students are presented in Table 3.

Table 3. The Results of Psychomotor Aspect in the First Cycle

\begin{tabular}{llcc}
\hline No. & Assessment Aspects & Score & Percentage \\
\hline 1 & Neatness & 114 & $79.2 \%$ \\
2 & Accuracy & 101 & $70.1 \%$ \\
3 & Group Discussion & 90 & $62.5 \%$ \\
4 & Cooperation & 108 & $75 \%$ \\
5 & Clarity & 102 & $70.8 \%$ \\
\hline & Average & $71.5 \%$ & \\
\hline
\end{tabular}

Table 3 informs that the average psychomotor value of students was 71.5 percent, with the highest psychomotor assessment obtained from the neatness indicators of 114 with a percentage value of 79.2. Therefore, the psychomotor scores of students in the first cycle are in the "good" category.

\section{The Results of Psychomotor Aspect in the Second Cycle}

Assessment of the psychomotor domain is obtained from the results of the assessment of practical activities. The results of the psychomotor aspects of students can be seen in Table 4 .

Table 4. The Results of Psychomotor Aspect in the Second Cycle

\begin{tabular}{llcc}
\hline No. & Assessment Aspects & Score & Percentage \\
\hline 1 & Neatness & 132 & $91.7 \%$ \\
2 & Accuracy & 132 & $91.7 \%$ \\
3 & Group Discussion & 114 & $79.2 \%$ \\
4 & Cooperation & 126 & $87.5 \%$ \\
5 & Clarity & 126 & $87.5 \%$ \\
\hline
\end{tabular}

According to Table 4, it is known that the average psychomotor value of students was 87.5 percent, with the highest psychomotor assessment obtained from the neatness indicator of 132 and the accuracy indicator of 132 with a percentage value of 91.7. Therefore, the acquisition of the participant's psychomotor value students in the second cycle are in the "very good" category.

Based on the research findings, it shows that the implementation of the STEMbased PjBL learning model can improve learning outcomes for students. These findings support the results of previous studies where the application of this model was able to improve student learning outcomes in the cognitive domain (Sumarni et al., 2019). The results obtained from first and second cycle show that the mastery of the material taught by the teacher has increased and more students who score above 
the Minimum Mastery Standard. Based on the results obtained regarding the cognitive and psychomotor domains in this study, it was known that there was an increase from cycle I to cycle II. Research conducted by Parno et al. (2020) also showed that this application was able to improve the skills of vocational students. If we take a look at the learning outcomes of students in the cognitive domain, there was an increase of 8.3 percent between learning outcomes in pretreatment and learning outcomes in cycle II and there was an increase of 8.4 percent from learning outcomes in cycle I with learning outcomes in the second cycle. Meanwhile, in the psychomotor domain, there was an increase of 22.4 percent between the learning outcomes of the first cycle students and the second cycle students.

The application of the STEM-based PjBL learning model on the basic competencies of work/office layouts implementation can improve student learning outcomes. In addition to improving learning outcomes, students can also explore through a project activity therefore, students can be actively involved in the work project process. Indeed, this will also support students in increasing their creativity in order to prepare the skills needed in the current era (Lutfi et al., 2018). This occurs because the implementation of the STEM-based PjBL learning model invites students to be able to carry out meaningful learning in understanding a concept. Research conducted by Alifa et al. (2018) suggest that learning by making projects carried out by students using the STEM approach can improve concepts, activeness, and skilled attitudes in students.

\section{CONCLUSION}

The obstacles during implementation of the STEM-based Project Based Learning (PjBL) learning model lies in the integration process in the planning stages of learning, particularly in integrating the elements of the approach with the designed competencies. This process requires teacher creativity. The factor of the availability of supporting facilities is also a determinant of the success rate of learning objectives. If the obstacles can be avoided then the combination of PjBL and STEM is an adequate combination. With the increase in the percentage of accuracy in implementing this learning model, it has also been able to improve student learning outcomes, namely the increase in the average value of student learning outcomes in both the cognitive and psychomotor domains.

\section{REFERENCES}

Afriana, J., Permanasari, A., \& Fitriani, A. (2016). Penerapan project-based learning terintegrasi STEM untuk meningkatkan literasi sains siswa ditinjau dari gender. Jurnal Inovasi Pendidikan IPA, 2(2), 202-212. https://doi.org/10.21831/jipi.v2i2.8561

Alifa, D. M., Azzahroh, F., \& Pangestu, I. R. (2018). Penerapan metode STEM (science, technology, engineering, mathematic) berbasis proyek untuk meningkatkan kreativitas siswa sma kelas XI pada materi gas ideal. Prosiding SNPS (Seminar Nasional Pendidikan Sains), 22. 
Bybee R. (2013). The case for STEM education: Challenges and opportunity, Virginia: NSTA press Arlington.

Darling-Hammond, L., Flook, L., Cook-Harvey, C., Barron, B., \& Osher, D. (2019). Implications for educational practice of the science of learning and development. Applied Developmental Science, 1-44. https://doi.org/10.1080/10888691.2018.1537791

Ejiwale, J. A. (2013). Barriers to successful implementation of STEM education. Journal of Education and Learning (EduLearn). https://doi.org/10.11591/edulearn.v7i2.220

Furi, L. M. I., Handayani, S., \& Maharani, S. (2018). Eksperimen model pembelajaran project-based learning dan project-based learning terintegrasi stem untuk mengingkatkan hasil belajar dan kreativitas siswa pada kompetensi dasar teknologi pengolahan susu. Jurnal Penelitian Pendidikan, 35(1), 49-60-60. https://doi.org/10.15294/jpp.v35i1.13886

Jauhariyyah, F. R., Suwono, H., \& Ibrohim. (2017). Science, technology, engineering, and mathematics project-based learning (STEM-PjBL) pada pembelajaran sains. Pros. Seminar Pend. IPA Pascasarjana UM.

Kang, N.-H. (2019). A review of the effect of integrated STEM or STEAM (science, technology, engineering, arts, and mathematics) education in South Korea. Asia-Pacific Science Education, 5(1), 6. https://doi.org/10.1186/s41029019-0034-y

Lutfi, L., Azis, A. A., \& Ismail, I. (2018). Pengaruh project-based learning terintegrasi stem terhadap literasi sains, kreativitas dan hasil belajar peserta didik. Seminar Nasional Biologi.

Maulana, M. (2020). Penerapan model project-based learning berbasis stem pada pembelajaran fisika siapkan kemandirian belajar peserta didik. Jurnal Teknodik, 2, 39. https://doi.org/10.32550/teknodik.v0i2.678

McCarthy, M., \& Carter, R. (2006). Explorations in corpus linguistics. Cambridge University Press.

Mulyasa. (2013). Pengembangan dan Implementasi kurikulum 2013. Bandung: Remaja Rosadakarya.

Nessa, W., Hartono, Y., \& Hiltrimartin, C. (2017). Pengembangan buku siswa materi jarak pada ruang dimensi tiga berbasis science, technology, engineering, and mathematics (STEM) problem-based learning di kelas X. Jurnal Elemen. https://doi.org/10.29408/jel.v3i1.273

Nurazizah, Suwarma, I. R., Jauhari, A., \& Kaniawati, I. (2018). Implementasi pembelajaran STEM: kajian terhadap pencapaian hasil belajar siswa. Prosiding Seminar Nasional Fisika (SINAFI) 2018.

Parno, Y. L., Munfaridah, N., Ali, M., Rosyidah, F. U. N., \& Indrasari, N. (2020). The effect of project-based learning-STEM on problem solving skills for students in the topic of electromagnetic induction. Journal of Physics: Conference Series, 1521, 022025. https://doi.org/10.1088/1742-6596/1521/2/022025

Quang, L., Hoang, L., Chuan, V., Nam, N., Anh, N., \& Nhung, V. (2015). Integrated science, technology, engineering and mathematics (STEM) education through active experience of designing technical toys in Vietnamese Schools. British Journal of Education, Society \& Behavioural Science. https://doi.org/10.9734/bjesbs/2015/19429 
Reis-Jorge, J. M. (2005). Developing teachers' knowledge and skills as researchers: A conceptual framework. Asia-Pacific Journal of Teacher Education, 33(3), 303-319. https://doi.org/10.1080/13598660500286309

Sukmawijaya, Y., Suhendar, S., \& Juhanda, A. (2019). Pengaruh model pembelajaran stem-pjbl terhadap kemampuan berpikir kreatif siswa pada materi pencemaran lingkungan. Jurnal BIOEDUIN, 9(2), 28-43. https://doi.org/10.15575/bioeduin.v9i2.5893

Sumarni, W., Wijayati, N., \& Supanti, S. (2019). Analisis kemampuan kognitif dan berpikir kreatif siswa melalui pembelajaran berbasis proyek berpendekatan STEM. J-PEK (Jurnal Pembelajaran Kimia), 4(1), 18-30. https://doi.org/10.17977/um026v4i12019p018

Utami, I. H., \& Hasanah, A. (2020). Kompetensi profesional guru dalam penerapan pembelajaran tematik di SD Negeri Maguwoharjo 1 Yogyakarta. Pionir: jurnal pendidikan, 8(2), 2. https://doi.org/10.22373/pjp.v8i2.6232

Winarno, A. (2015). Pengantar pendidikan. UM Press Malang. 